\title{
TheTraces of Ideological Battle in Text Coverage Case Sues Divorce Julia Perez Over Her Husband Gaston Castanno at Seleb on News MNC TV Critical Discourse Analysis of Norman Faircloug
}

\author{
Laksmi Rachmari ${ }^{1}$ \\ \{laksmi.ozil@gmail.com $\left.{ }^{1}\right\}$ \\ Faculty of Communication, Universitas Budi Luhur, Jl. Ciledug Raya, Jakarta, Indonesia ${ }^{1}$
}

\begin{abstract}
This research seeks to track the traces of ideological contention in text coverage of divorce sue case of Julia Perez over her husband Gaston Castanno at Seleb on News , MNC TV. This study uses a qualitative approach with Critical Discourse Analysis (CDA) method of Norman Fairclough and focuses on three dimensions. Those are text, discursive practices and social praxis. Journalists, reporters, and editors have full authority over the word selection to use. At the text level, the researcher studied it using framing analysis of Robert N. Entman. On its news narration, Seleb on News MNC TV brought the issue of divorce Jupe over Gaston Castano to law sphere. Gaston Castano is positioned as the cause of the problem, Julia Perez (Jupe) is positioned as a hero as well as a victim. Moral claim of happiness deserves to be fought for. Problem solving proposed by Seleb on News in news frame is that Jupe has a right to be happy, Gaston deserves to be divorced. In discursive practice, the researcher tries to dismantle the ideology or interests that the depiction of women who sued for divorce because of the violence that occurred in the household is a form of news commodification as well as strategy of perpetuating patriarchal ideology. Julia Perez's divorce phrase is told in a dramatic and moving way, selling women's sadness and tears as merchandise while perpetuating patriarchal cultural practices by showing depictions sacrificing women as weak creatures.
\end{abstract}

Keywords: Language, Ideology, Woman, News.

\section{Introduction}

Even though Indonesia already has Law on the elimination of domestic violence No.23/2004, women in Indonesia are still vulnerable to be victims of violence. The 2017 Annual Report (AR) issued by national commissions of woman documented several cases reported and handled by state agencies and service agencies.

There were 259,150 cases of violence against women that occurred during the year 2016 . 10,205 cases of which were cases of domestic violence. Of the 10,205 cases of domestic violence, violence against wives topped 57 percent (5,784 cases), followed by violence in the racial that was 21 percent and violence against girls, which was 18 percent. The rest is violence perpetrated by ex-husbands, ex-boyfriends, and other personnel violence. The most prominent forms of violence in the domain of domestic violence were physical violence (42 percent), sexual violence (34 percent), psychic (14 percent), and economy (10 percent) [1]. 
The Law on the Elimination of Domestic Violence (UU PKDRT) No.23 / 2004 defines domestic violence as every act against a person, especially women, resulting in physical, sexual, psychological, and / or abandonment of households including to commit acts, coercion, or deprivation of liberty unlawfully within the scope of the household.

Ironically, someone frequently does not realize that she is a victim of domestic violence. Therefore, the socialization of the Law on the elimination of domestic violence especially among the wider community is something very urgent. This is where the function of television as part of the mass media to run its role, in addition to providing information, television also serves to educate the public in the process of distribution of information related to women's rights and gender justice.

Domestic violence can happen to anyone, both celebrities and ordinary people. Some of the artists featured in brilio.net claimed to experience domestic violence ranging from verbal abuse to beatings. Jennifer Lopez, Cornelia Agatha, Manohara Odelia Pinot, Mariah Carey, Nia Daniaty, Rahma Azhari, Maia Estianty, Oki Agustina and Sheila Marcia [2].

The highest point of domestic violence is the loss of a spouse's life. Forensic psychologist Reza Indragiri suggests a divorce is the last step taken when there is a failure in anger management [3]. Yet the decision to sue for divorce for women is not easy, especially because of the negative stigma attached by the community to women who become widows. Both in the sphere of fiction or non-fiction messages are produced by the mass media. The issue surrounding widows is constructed in such a way as to produce negative depictions that eventually evolve in society. In the sphere of fiction for example, widows are told as a figure of sexy women and teasers both on television and in cinema.

Mass media basically does not present reality, but rather defines the meaning of that reality through the words it chooses. Every word the media uses to define reality is an ideological practice.

In 2016, it was recorded 11 cases of celebrity divorce. Of the 11 cases, 9 is a divorce case where the plaintiff is a woman (wife). Thursday, May 12, 2016, for the second time artist Julia Peres officially bears Widows status. South Jakarta District Court Judge granted a divorce sue of the woman whose real name is Yuli Rachmawati for her husband Gaston Castanno. In this case the Judge also obliged Gaston Castanno to pay the livelihood to Jupe as long as Jupe was not remarried with a nominal amount of 15 million rupiah per month for having abandoned her living [4].

Infotainment is news that provides information about the lives of people who are known to the public (celebrities) and most of them work in the entertainment industry such as movie players / soap operas, singers, and so on. The news about them is also called infotainment. Infotainment is one form of hard news because it contains information that must be immediately aired. Nowadays, infotainment is presented in a separate news program and specifically displays news about the lives of celebrities [5]. Infotainment is also often referred to as a journalism couch, a type of journalism that offers sensational news, more personalized, with celebrity attention to its coverage.

Seleb on News MNC TV is an infotainment program that goes into the top 5 of the highest rating. In contrast to infotainment programs in general, infotainment program Seleb On News is in house production MNC TV under the Department News or MNC News, so it is expected to put forward the rules of journalism when preaching an event.

We often see the mass media as a neutral means of communication. Yet what really happened was not so. The mass media is in the midst of a social reality filled with various interests, conflicts. The media is also an instrument of power and means for ideological struggle. 
There is a price in the news [6]. When a news edition produces a story, it selects the selection process and chooses which messages will be delivered to the audience. In the process of selection is the background and interests of individuals and interests of media organizations cannot be avoided in constructing reality. They often perform actions that ultimately benefit companies / media organizations.

For them, information market (news business) is to seek profit in the first place [7]. It should not be late, should not be preceded by the media or other television stations, avoid rating down, and etc. In this case, media coverage and all activities of the company is measured by how much the selling value that can be generated from news.

The use of language in news is not actually transparent, in the sense that a discourse is written in the news text loaded with rhetoric, manipulation and misdirection. In this case the existing discourse does not directly express the sincere intentions of the news writer.

On the other hand, our social structure that still adheres to the patriarchal system seems to provide an opportunity for media companies in building their business. The media sphere is a patriarchal sphere; the parties involved in the media are mostly male [8].

Women are often depicted in mass media with constructions that harm women. Women are depicted as weak creatures, only possessing a domestic role, and being portrayed as mere 'sweetener', and experiencing body exploitation. Exploiting women's bodies is a low-risk business for patriarchal culture. Here, the mass media has sacrificed women in its construction; hence the patriarchal culture then becomes a 'machine' suppressor after market logic.

\section{Methods}

This study used a qualitative approach with the method of Critical Discourse Analysis of Norman Fairclogh. Critical Discourse Analysis tries to dismantle something wrong in society, such as injustice, equality, restriction of freedom or discrimination [7].

Fairclough told there are three-dimensional methods of discourse analysis. Discourse, and any specific instance of discursive practice, is seen as simultaneously (i) a language text, spoken or written, (ii) discourse practice (text production and text interpretation), (iii) sociocultural practice [9].

The text becomes a social struggle site [7]. Through text we can trace the track of ideological struggle in order to dominate or hegemony. Here is the role of critical Discourse Analysis, i.e. to melt and track the existence of ideology.

\section{Results \& Discussion}

To analyze the text, researchers used framing analysis techniques Robert N. Entman. Framing is a method of presenting reality where the truth is not totally denied, but rather "bending" subtly by providing a projection on a particular aspect. Aspects that are hidden by the media then become forgotten even not paid attention at all by audiences.

Entman sees framing in two major dimensions: selection of issues and emphasis or protruding aspects. In the Entman concept, framing basically refers to the giving of 
definitions, explanations, evaluations and recommendations in a discourse to emphasize a particular frame of mind for discourse events.

The concept of framing of the Entman describes extensively how events are interpreted and marked by journalists. Entman divides the framing device into four elements as follows: First, to define problems. This element is the master frame (most important frame). It emphasizes on how events are understood by journalists. The same event can be understood in different ways and frames. Second, diagnose causes, is a framing element to frame anyone who is considered an actor of an event. The causes in this context could be what or who. Third, creating moral judgment. Creating moral judgment is framing analysis that is used to justify / argue for defining the created problem. Fourth, treatment recommendation. This element is used to assess what is desired by journalists and what solution that was chosen to solve the problem. The settlement is of course highly dependent on how the event was seen and who was seen as the cause of the problem [10]. A well-crafted reality will allow the opportunity of reality to be noticed and influence the audience in understanding that reality. The protrusion here is how journalists make existing information more interesting, meaningful, or easier to remember by audiences.

\subsection{The Seleb News Frame on News MNC TV}

Define Problem, Seleb on News defines Jupe's divorce case over Gaston Castano into the sphere of law. Everything from the news about Jupe's divorce to her husband Gaston Castano is highlighted from the side of the Law. Diagnose Causes, in the whole text of Seleb on News, defines the cause of the problem in this case is Gaston Castano, the artist's husband. Gaston is portrayed as a play boy and materialistic figure who utilizes Julia Perez. This can be seen in the following text and images:

Besides rumored to make affairs, gaston is also suspected as a womanizer who only exploits jupe starting from luxury car rewarded for gaston as a birthday gift from jupe and gaston's cost of living that are charged to jupe during their relationship or during gaston having injury causing him not to be able to play soccer/jupe is the one who is responsible gaston's cost of living.

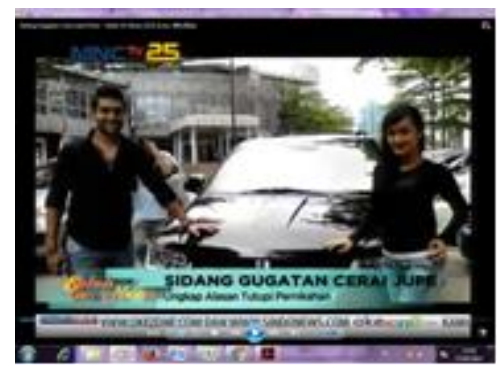


Fig. 1. Gaston, a Womanizer [11]

The In this context, Seleb on News Seleb on News uses words as well as sentences to reinforce its message frame, like the word "making affair" that illustrates that Gaston is a disloyal man, betrayed of marriage, torturing Jupe from his psychological side. The word "Womanizer", "Exploit Jupe" "Luxury Car", "Jupe Is The One Who Fulfill Gaston's Daily Needs" is a description of the forms of domestic violence that Gaston has done to his wife. The type of violence that Gaston does in this case is the violence in economic sphere. Gaston also abandoned his responsibility as husband that should be the one who fulfill household needs.

Further Seleb on News also featured Gaston's facts as a husband who had abandoned his livelihood by quoting Jupe's statement. "During this time Gaston boasted that in his country he had no obligation to support me, he was wrong. In Indonesia men should fulfill household needs, moreover he knows how law in Indonesia works. Now he understands that the law in Indonesia respects the rights of women and he now has to pay, it is required 15 Million per month ".

The News writer also positioned Jupe as both a victim and a hero. Jupe is told in news narrative as a woman who loves Gaston sincerely. Jupe had sacrificed everything for the man she loved, though eventually Jupe was finally disappointed. This can be seen in the following news narrative:

Divorce court/dangdut singer julia perez/with an argentina soccer player/gaston castano/held again yesterday//but//unlike previously/this time artist, jupe, looks tougher than usually//offically divorced and becomes widow//jupe admitted relief and happy/because eventually she is free from her suffering this whole time//[12] Seleb on News also quoted Jupe's statement to strengthen the frame, "I do not cry, do I cry? I'm so happy. Heloo I'm the happiest girl in the world now. This is my independence day. "

In addition, besides using words, sentences and pictures, Seleb on News also use music illustration in the form of piece of song "I Want to Break Free" a song by Dewa band. The contents of the song's lyrics describe a condition or circumstance in which a person has been freed from a large burden or pressure. The news writer intends to relate the conditions experienced by Jupe as depicted in the lyrics of the song. The news writer intends to show that divorce or women who are sued for divorce are not always negative, women are entitled to struggle their happiness especially when experiences violence in the household. Jupe is described as a tough figure who dares to "fight" the culture or values that have existed in the community for a long time. Jupe prefers to be a widow rather than suffering in marriage bonds.

Creating Moral Judgment. Seleb on News contains a moral claim that happiness is the right of every human being to be fought for Treatment Recommendation. Based on the background of defining the problem, determining the cause of the problem or the victim as well as the moral claims presented, Seleb on News provides problem solving that Jupe deserves to be happy and Gaston deserves to be divorced.

\subsection{Discursive Practices}

Journalists live in media institutions with their own set of rules, work patterns, habits, rules, norms, ethics and routines. MNC TV is a commercial television station that lives in the 
midst of the competition of the television industry. Infotainment is one of the flagship programs of commercial television stations. The perception about the lives of artists becomes the "meal" of infotainment journalists.

"Like the usual infotainment, Seleb on News also holds editorial meetings and projection meetings. First, we hold meeting and plan what we will have for tomorrow (publish what news for tomorrow, red), we raise Jupe's case is because the divorce court is running at this time and it attracts a lot of attention from television viewers". [13] The higher value of an event's news is, the higher selling price will be. It ultimately led to the fight for the high rating. Julia Perez's divorce sue against her husband contained news of conflict, human interest, prominence, impact, actual (at the time), so it is not surprising that television stations are trying to be able to broadcast the latest information about Julia Perez's divorce case. Seleb on News also made efforts to not lose in the competition among others by holding a live report from the location in order to be the first one to broadcasts and it is also for specificity reasons, which distinguishes the program from other infotainment. "There is also live. It is more updated than the other infotainments, because other infotainments perhaps will discuss Jupe only at the core of the event, but if we attend directly in the spot, it is as if viewers are presented directly from the scene "[13].

Seleb on News also take advantage of internet technology to strengthen its position in the middle of the competition.

"We would like to grab Jupe's fans, young mothers aged 20-40 years old. In Instagram, there is also Jupelicius, Jupe's fans (followers). Jupe is their idol; they want to know all about their idol, they want their idol backed up completely. So when the news gets aired, we tag all Jupe's followers to watch. We go to their Instagram, and we also have their own Instagram, Seleb on News.MNCTV. Now because of social media era, we have to participate in it as well. We have Instagram, Facebook, and twitter. We have a social media team. Before the program is aired, we posted such as streaming video trailer on twitter for promotion and the viewers will get full content of the program that day on TV program"[13].

\subsection{In News Construction Jupe Is Portrayed As both a Victim and a Hero}

The events presented in the news are not value-free. News is formed from the journalist's construction based on reality. Here, reporters and editors have full authority to choose what words to use. They can choose one of many rows of words that are similar in meaning but have different "taste".

"We do not want to judge him (Gaston). We want to give lesson to the female viewers that Jupe is actually weak, and Jupe is actually a person who gets hurt. Because of her journey of love with Gaston that we see, Jupe has already struggled a lot for it. Although in the end, Jupe's parents do not agree with the relationship, Jupe insisted on sacrificing for her love. However, her man betrays Jupe eventually" [13].

Associated with the position of women who sued for divorce her husband, Iswanti as producer Seleb on News argued that it was the right of women. She thought that both men and women have equal rights.

"It is really the last option. The last option after everything cannot solve the problem and other ways have been taken but the problem is not over yet. In fact we women have the right to do it [13].

\subsection{Socio Cultural Practice}


The idea of commodification begins with Marxist thought about mass production, about the ways in which the social relations of authority are controlled by commercial interests or economic determination [6]. News is part of the chaos of the value system and materialism. There is a price on the news. News becomes a commodity idea, because news is bought and sold through news agencies.

In media industry, commodities sold or exchanged are not goods or objects in the physical sense, but commodities are formulated in the aesthetic price presented in the form of media production. Because in the television industry, the things that are sold or exchanged are not objects or goods in physical sense. Rather commodities are formulated in aesthetic works that are deliberately displayed.

One of the strategies in dealing with competition with other television stages is to produce television programs that fit the market taste. Therefore, to raise the rating, editors of Seleb on News have several strategies to raise their rating, which is intrinsic commodities in the program, such as interesting news packaging, live report from the scene, or utilizing communication technology such as Instagram, Facebook or Twitter to promote the program.

Mass media requires journalists who are in charge of finding, collecting and processing news that will be distributed to the public. Indeed, the task of journalists is to express facts and or opinions that contain facts, convey the truth and justice. In addition, they explain actual matters and educate the community. But this work is not an easy job since there are various interests that will later participate, and eventually gives shape to the truth that will be delivered [8].

Iswanti, as producer of Seleb on News Program and as a woman, would like to defend her people. She tried to fight in the news text she produced, such as trying to portray the figure of Jupe as a tough female figure, breaking the negative stigma about women suing her husband's divorce. However, Iswanti is part of MNC TV, where the media world is currently patriarchal world since people who are involved in the media world are dominated by men. Moreover, Iswanti is also in the global patriarchal system. Patriarchate is an asymmetric relationship between men and women who place men more dominant than women.

Mass media has the power and a important role in shaping reality. The reality created by the media is a symbolic reality that is the product or engineering of the managers (editors, journalists, producers, and all the people who work on it) they choose the reality they want to show as well as hide the reality that is not supposed to support the news construction.

In the text produced by the editor of Seleb on News, it participates in solidifying patriarchal ideology whether they realize it or not. It describes women (Jupe) as a weak figure and sells suffering and tears of women. This is seen in the following text:

Besides rumored to make affairs, gaston is also suspected as a womanizer who only exploits jupe starting from luxury car rewarded for gaston as a birthday gift from jupe and gaston's cost of living that are charged to jupe during their relationship or during gaston having injury causing him not to be able to play soccer /jupe is the one who is responsible gaston's cost of living [11].

In this news text Seleb On News positions Gaston as a dominant position and Jupe is in a weak position through words and phrases such as "making affair", "a womanizer who only exploits Jupe", "a luxury car rewarded for Gaston's as a birthday gift from Jupe "," cost of living that are charged to Jupe during their relationship", and "Jupe is the one who is responsible for Gaston's cost of living. 
Seleb on News also represents the figure of men as the ruling over women. In this case, media participates to perpetuate the power of patriarchy ideology. This is seen in the following news text:

Again julia perez also known as jupe is disappointed / when attends the second court/divorce sue over her husband, gaston castano / in the district court of south jakarta south / last wednesday //artists having bald head (jupe) felt annoyed / because through the social media, she has asked gaston nicely / to come to their divorce court //

Jupe's Statement: "I already posted on my twitter. I know that he is frequently active in social media. As proof, he usually posts when he goes to some places. At first (divorce court) he stated that he could not attend. And there is no news about him. Instead, he went holidays with his friends and had party on the beach. It showed that he does not respect the divorce court as well. By showing his attitude, I do hope that the judge directly grants my divorce sue and ends the divorce court. I really cannot wait. Moreover I would like to have a big party in my house as thanksgiving"[14].

All that is done consciously or not by text producers: "We do not want to judge him (Gaston). We want to give lesson to the female viewers that Jupe is actually weak, and Jupe is actually a person who gets hurt. Because of her journey of love with Gaston that we see, Jupe has already struggled a lot for it. Although in the end, Jupe's parents do not agree with the relationship, Jupe insisted on sacrificing for her love. However, her man betrays Jupe eventually" [13].

In addition to patriarchal ideology, competition with other TV stations, Seleb on News will perform various ways to attract the attention of its viewers. Viewers' attention is then recorded in rating data and it was sold to advertisers.

Taking the term of T. Titi Widianingsih, patriarchal system puts media, in this case, Seleb on News is in a state of blessing in disguise for media companies in building their business.

In the middle of highly patriarchal society, the media (Seleb on News) sacrifices women in their news texts and sells women's sorrow and tears.

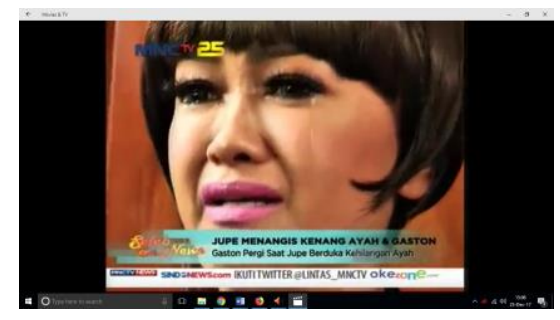

Fig. 2. Jupe cries when remembersher father and Gaston [14].

\section{Conclusion}


Basically, the mass media, in this case television, does not reproduce reality, but defines the reality that exists through the use of words, sentences or images. Each word used in a media text shows an ideological practice.

As part of the mass media, News editor Seleb on News MNC TV is in two major pressures; economic and patriarchal cultural pressures. Through news texts, the editor of Seleb on News has made women's issue as a commodity.

Our mental structure is related to ideology through language. Language is not a neutral but ambiguous communication tool. Because through Language, certain ideologies formed us and we do not realize about it.

Julia Perez's divorce phrase is told in a dramatic and moving way, selling women's sadness and tears as merchandise while perpetuating patriarchal cultural practices by showing depictions sacrificing women as weak creatures.

\section{References}

[1]H. Diani, "Komnas Perempuan: Kasus KDRT Terhadap Istri Tetap Tertinggi Setiap Tahun," Magdalene.co, 2017. .

[2]A. R. Dewi, "10 Artis Ini Mengaku Korban KDRT, Pelecehan Verbal Hingga Pemukulan,” Brilio.net, 2016. .

[3]B. Desideria, "Pernikahan Penuh KDRT, Perceraian Jalan Terbaik,” liputan6.com, 2017. .

[4]L. Rachmaria, "Frame Of Female Actress Divorcement ( Case Study of Julia Perez Divorcement onto Her Husband Gaston Castano in Seleb On News , MNC TV )," Int. J. Stud. Child. Women, Elder. Disabl. People, vol. 2, no. Frame of Female Actress Divorcement in Infotainment Programme (Case Studyof Julia Perez Divorcement Onto Her Husband Gaston Castanno in Seleb On News, MNC TV), pp. 52-57, 2017.

[5]Morissan, Jurnalis Televisi Mutakhir. Kencana Prenanda Media Grup, 2008.

[6]G. Burton, Discusses an introductory television to television studies. Jalasutra Yogyakarta, 2007.

[7]Haryatmoko, Critical Discourse Analysis (Analisis Wacana Kritis) Landasan Teori, Metodologi dan Penerapan. Yogyakarta: Kanisius, 2016.

[8]T. T. Widianingsih, "Konstruksi Realitas Perempuan dalam Berita Harian Kompas," Komunitas, vol. 1 , no. Juli, pp. 24-50, 2011.

[9]N. Fairclough, Critical Discourse analysis the critical study of language, Second. Pearson Education Limited, 2010.

[10]Eriyanto, Analisis Framing: Konstruksi, Ideologi dan Politik Media. Yogyakarta:Lkis Printing Cemerlang, 2012.

[11]Iswanti, "Hari Ini Sidang Perdana Jupe," MNC TV, 2016.

[12]Iswanti, “Jupe Resmi Menjanda Lagi,” MNC TV, 2016.

[13]L. Rachmaria, "Interview Seleb On News Producer," 2017.

[14]Iswanti, “Julia Perez Kecewa dan Kesal,” MNC TV, 2016. 